\title{
The Political Economy of the Harmonisation of the Nguni and the Sotho Languages
}

\author{
Neville Alexander, Project for the Study of Alternative Education \\ in South Africa, University of Cape Town, South Africa
}

\begin{abstract}
The author believes that it is essential to revisit the issue of the harmonisation of the African languages of South Africa. He maintains that most people who have been writing on the subject locally have not understood the kemel of the original Nhlapo-Alexander proposal and restates the economic and political arguments for it. Because there are no "linguistic" barriers to the realisation of this proposal, he concludes that the main obstacle is the lack of political will and appeals to the relevant academics and political/cultural leadership of the country to reconsider the issue against the background of a similar movement in the rest of the continent.
\end{abstract}

Keywords: STANDARDISATION, HARMONISATION, LANGUAGE PLANNING, STANDARD NGUNI, STANDARD SOTHO, ETHNICITY, NATION-BUILDING, AFRICAN LANGUAGES, AUSBAU LANGUAGES, LANGUAGE ENGINEERING, MUTUAL INTELLIGIBILITY, PAN SOUTH AFRICAN LANGUAGE BOARD, LANGUAGE MODERNISATION

Opsomming: Die polities-ekonomiese aspekte van die harmonisering van die Nguni- en die Sothotale. Die outeur is van mening dat dit noodsaaklik is om weer te kyk na die harmonisering van die Afrikatale van Suid-Afrika. Hy beweer dat die meeste mense wat plaaslik oor hierdie onderwerp geskryf het, nie die kem van die oorspronklike Nhlapo-Alexander-voorstel verstaan het nie, en hy stel weer die ekonomiese en politieke argumente ten gunste daarvan. Aangesien daar geen "taalkundige" grense is vir die daarstelling van hierdie voorstel nie, kom hy tot die gevolgtrekking dat die hoofstruikelblok die gebrek aan politieke wilskrag is. Hy beroep hom op die relevante akademici en politieke/kulturele leiers van die land om hierdie saak te heroorweeg teen die agtergrond van 'n soortgelyke beweging in die res van die kontinent.

Sleutelwoorde: STANDAARDISERING, HARMONISERING, TAALBEPLANNING, STANDAARD NGUNI, STANDAARD SOTHO, ETNISITEIT, NASIEBOU, AFRIKATALE, AUSBAUTALE, TAALMANIPULERING, WEDERSYDSE VERSTAANBAARHEID, PAN-SUID-AFRIKAANSE TAALRAAD, TAALVERNUWING

In view of the erroneous and misleading opinions expressed by Louwrens (1997: 248-250) and because the question of the harmonisation of the Nguni and the Sotho languages of South Africa is bound to become more, not less, relevant in the near future, it is appropriate that this still contentious matter be looked at 
once again. ${ }^{1}$

To begin with, let me restate in my own original words what is being proposed. In the first version of the proposal, I wrote:

The development of a written Standard Nguni and a Standard Sotho, as an initial phase of a very long-term process of "uniformation", need not and will not lead to the disappearance of Zulu, Xhosa, Ndebele, Siswati, Sipedi and Tswana and their dialects ... Indeed, subject to the availability of resources, they will be encouraged in print in literature of all kinds. The main difference will be that in all formal situations, including the crucial area of education, the Standard Nguni or Standard Sotho forms will be promoted. It is to be expected that, over time, the spoken standard - used in formal and relatively formal situations - will begin to approximate to the written standard, even though individuals will inevitably betray their regional or social origins via their accent and intonation as they do in all similar situations elsewhere in the world. (Alexander 1989: 64)

Compare this with the aboriginal suggestion of Jacob Nhlapo:

Even though there are many Bantu languages in South Africa, we can agree that Xhosa, Sotho, Zulu, Tswana and Pedi are the chief ones. They are the ones which are spoken by most Bantu, and most Bantu books are written in them. Let it be said here that these books are bought mostly by school children ... From these tongues we can at first build up two languages. Zulu and Xhosa together with the branches known as Ndebele, Swazi, Baca, etc., are so much alike that, put together they can make one good strong language called Nguni. In the same way, Pedi, Tswana, and Southern Sotho, together with Kxatla, Tlokwa, etc., are so much alike that joined together they can make one good strong language called Sotho.

Writing is the best way to make languages grow together ... (Nhlapo 1944)

The essential argument here is based on the mutual intelligibility of the varieties which make up the two language clusters even though one of the main reasons for the proposal is derived from the economic rationality thereof and another from its political appropriateness in the context of the avowed nationbuilding, antitribalist strategy of the new government. In other words, the original proposal was directed at language specialists and linguists and was intended to remind them that linguistically there was (and is) nothing to prevent the planned convergence towards a written Standard Nguni and a written Standard Sotho. This reminder was all the more necessary as many years of

As background to this contribution, readers are referred to my article (Alexander 1992) in which the rationale for the harmonisation proposal is canvassed in detail. 
apartheid-inspired social (and linguistic) engineering had created stereotypes of racial and ethnic separateness which would have to be weakened and even eliminated if the promotion of national unity was to have any chance of success at all. Vested interests in separateness and Ausbau strategies ${ }^{2}$ in the domain of language policy and language development would have to be identified and countered if the notion of the two written standards was to make any headway.

The vested interests are obvious. Academics who specialise in particular varieties of the languages concerned as well as traditional leadership have a clear reason for being suspicious and sceptical. However, all of this is misplaced and it is essential that the appropriate and relevant historical and comparative information be placed before these interest groups so that they may realise that far from the proposal for harmonisation being detrimental, tendentially and actually, to their special interests, it will in fact lead to an efflorescence of dialectology and of the study of particular varieties. This is what has happened wherever such planned convergence (standardisation) has been undertaken. And it is so obvious that this must be a spin-off of standardisation initiatives that one wonders why it is necessary to argue the point at all. One reason that is usually implicitly but sometimes explicitly advanced for opposition to the proposal is the reactionary notion of "ethnicity" derived from an outmoded and dated Eurocentric paradigm of identity formation. This, in my view, lies at the heart of Louwrens's unsubtle perception of the language domain and language policy and planning in postapartheid South Africa (see especially Louwrens 1997: 248).

By way of illustrating this proposition as well as that alluded to earlier, that harmonisation will become more, not less, relevant in the near future, it is necessary to point out that within the past 12 months or so, the Pan South African Language Board has received no fewer than five different requests from relatively small groups of people seeking a change of status for their languages. Although the specifics are different in each case, the approaches by groups purporting to represent Indian, Khoi and San, Northern Ndebele, Puthi and Lovedu "linguistic communities" in some cases for recognition as "official languages" forespell the inevitability of harmonisation (or further standardisation) of the Nguni and Sotho clusters. Since it is clear that there can be no recognition of more "languages" - quite apart from the fact that the recognition of the 11 languages was a political decision based on a compromise and had nothing to

Ausbau languages are those that are so similar in grammar and lexicon to other, stronger, previously recognised languages that their language authorities often attempt to maximize the differences between themselves and their Big Brothers by multiplying or magnifying them through adopting or creating distinctive paradigms for neologisms, word order and grammar, particularly in their written forms. Thus Ausbau languages are languages by effort, i.e. they are consciously built away ("ausgebaut") from other, more powerful and basically similar languages so as not to be considered mere dialects of the latter, but rather, to be viewed as obviously distinctive languages in their own right ... (Fishman 1974). Also see Msimang 1996, where evidence for the adoption of this strategy by the apartheid sucial engineers is given very clearly. 
do, with whether the 11 were or are "languages" as opposed to "dialects" - I believe that, increasingly, political and academic planners are going to have to come back to the harmonisation proposal. For this reason, among others, it is essential that the political and economic rationality of going down the road of harmonisation be demonstrated. Paradoxically, the danger of opening the Pandora's box of tribal and ethnic strife will impell those who fear the consequences of such destabilisation to turn towards harmonisation as the way to resolve the dilemma of recognising some "dialects" as official languages but not others.

In order to clear up another confusion that has crept into this debate, it is necessary to note that those of us who have consistently propagated harmonisation or unification of the "mutually intelligible" varieties of the two language clusters have never suggested that this should be a sudden, short-term, cutand-paste operation undertaken by some faceless language engineers in smokefilled backrooms. This image of a sinister strategy for Jacobinic homogenisation of the unsuspecting "people" is a caricature which it is all too easy to pillory and even to kill off. Fortunately, those who have actually read (and understood) the proposal realise that it is based on a wealth of comparative, historical and linguistic good sense and that it will not disappear so easily. Some suggestions about how the process of harmonisation might be initiated and sustained (see, for example, Glaughton and Gough 1996, Msimang 1996 and Cluver 1990) are eminently discussable and will become respectable as soon as the requisite sociolinguistic and political atmosphere comes into being. To this, one should add the not inconsiderable fact that the actual practice of SABC TV, which uses all the Nguni and the Sotho varieties on a specific channel as a matter of economic necessity, besides other reasons, has already taken the process a long way forward even though few people would recognise or deliberately describe this practice in terms of harmonisation.

Two years ago, when Professor Kwesi Prah of the University of the Western Cape organised a highly significant seminar in Cape Town on harmonisation and standardisation of African languages, numerous African scholars from countries as far apart as Ghana, Cameroon and Lesotho and South Africa demonstrated one after the other that there is no linguistic-technical reason why these processes cannot be promoted and that there is every political and economic reason why they should be promoted. Citation needs only be made from two of the most relevant papers delivered at that seminar. Thus, Professor Emenanjo of the National Institute for Nigerian Languages, in an erudite and elegant essay on Modern Standard Igbo showed how this language differs from previous artificial academic attempts to "harmonise" different varieties of the Igbo continuum.

Unlike the three extinct "standards" which were artificially created to fill a vacuum, the extant standard is the product of the dynamic forces of inclusion and exclusion necessitated by the imperatives of modernisation, and engineered by the dialect-neutral Society for Promoting Igbo 
Language and Culture through its language think-tank: the Igbo Standardization Committee. Motivated and propelled by its own internal logic, with its own verifiable and quantifiable rules which include eclecticism in the choice and use of lexical items, Modern Standard Igbo is distinct from any and all of the live Igbo dialects, and any and all of the "dead" Igbo standards in its pan-Igbo acceptability and patronage as well as its valency in metalanguage. Standard Igbo has the richest lexical inventory among all other varieties of Igbo. (Emenanjo 1996: 3)

In a short contribution comparing the modernisation of Japanese and Kiswahili, Professor Miyamoto of Osaka University noted:

(Just) as Shona in Zimbabwe is sometimes said to be "a language which everyone writes and nobody speaks", so it was with Standard Swahili at the beginning. But today the written form of Swahili has strongly influenced the spoken form, as publications increase and the number of speakers of Swahili as a second language increases. The meaning of modernisation of any language is not always clear but some radical planning seems necessary, especially in a multilingual situation or in ... critical ... (periods) of history ... The ... (most important) factor ... (for) the success of any language planning seems ... (to be the promise) that it will create larger and better job-markets for the common masses who will speak and write ... (the language concerned). (Miyamoto 1996: 10-11)

It is these political and economic moments of the argument that will in future have to become the focus of our research if we are to pursue the matter of harmonisation as a practical undertaking during the next few years.

In a multilingual ecology where English is King of the Languages, it makes eminent sense to ensure that for the sake of the vast majority of the population for whom English will always be a foreign language, there are strong African languages with a solid infrastructure of literacy, interpreting and translation competence. In South Africa, as in many other African countries, such an infrastructure will be created much more easily and effectively through the harmonisation of existing varieties of indigenous language clusters wherever and whenever this is possible and feasible. The essential next step has to be initiated by the political and cultural leadership in and across the relevant African countries. Men and women who have the vision and the courage to be "unpopular" for a while because of the unavoidable objections that will be forthcoming from those with vested interests and those who are restricted by the myopia of hegemonic agendas simply have to realise that they have to publish the information arid produce the prototypical examples of texts that will persuade the "masses" of the feasibility of this historic undertaking. And, they have to realise the Biblical prophesy: "Where there is no vision, the people perish!"

For it remains a stubborn fact that the users of the varieties of a language are in the final analysis the people who decide whether theirs is a different 
guage" from the variety spoken in the neighbouring village. It is, however, the prerogative of government to intervene and to shape people's consciousness differently, provided this happens in a transparent and democratic manner. If this were not the case, what right would the government of this, or any other, country have to persuade men and women to wear condoms in order to lessen the danger of spreading Aids? Politically speaking, we have to persuade people who speak a Nguni or a Sotho variety that these are in fact "dialects of each other", i.e., Zulu is a dialect of Xhosa and vice versa, for example. The implicit political agenda in such a statement ought not to be problematical to anyone committed to the democratic transition in South Africa. The kind of objection or fear raised by Louwrens (1997) is, as I have indicated, either based on a misconception of the dynamics of harmonisation as a process or it derives from a dated paradigm.

We must, it is clear, bear in mind that the strength of tradition, especially where the languages have been written for more than a century and have relatively strong literary treasuries will represent a retarding moment. This is, however, not insuperable at all as recent examples in Africa itself and in countries such as Estonia demonstrate.

Practically, for the next decade or so, this implies that a text that is composed predominantly in Xhosa but which includes many lexical, syntactical and morphological elements from one or more of the other varieties of Nguni will be labelled a "Nguni" text; similarly, if it were to be composed predominantly in Zulu or Swati or Ndebele. The necessary condition for this to happen is that comprehensive dictionaries embracing all the relevant varieties would have to become readily available in different formats that can be used for different purposes. Texts would also necessarily have glossaries or notes by means of which peculiarities deriving from one or other variety would be explicated. In an earlier period, many Dutch texts carried such glossaries in Afrikaans and it is a practice that is widespread in similar situations elsewhere. It ought to be obvious that such an approach is economically rational since the need to translate and to print different (more costly per unit) texts falls away.

The other related but enormous task that awaits us in this undertaking is the revival or the establishment of a reading culture in the African languages. This is a matter the need for which is so well attested as to require no further substantiation. What is clear is that the educational structures, especially those devoted to early childhood development, the preprimary and elementary schools, will play the major role in this regard. Besides the need to conduct radically new research into the acquisition of literacy by young children and to retrain teachers throughout the continent along appropriate lines, it is clear that one of the great virtually unthought-of tasks is the translation into the African languages for use at all levels of sophistication of the great works of world including African - literature, science and philosophy.

Sociolinguists, lexicographers, terminologists, terminographers, translators, interpreters and other language and educational specialists, together with enlightened political leadership will have to concert their efforts in order to cre- 
ate the framework within which the harmonisation of the Nguni and Sotho language varieties respectively can take place. Any African "renaissance" will be stillborn unless this process is initiated.

\section{References}

Alexander, N. 1989. Language Policy and National Unity in South Africa/Azania. Cape Town: Buchu Books.

Alexander, N. 1992. South Africa: Harmonising Nguni and Sotho. Crawhall, N. (Ed). 1992. Democratically Speaking: International Perspectives on Language Planning. Cape Town: National Language Project.

Cluver, A. (Ed). 1990. Taalbeplanning in Suid-Afrika. Lecture No. 6 of Study Guide, Linguistiek. Studiegids 2 vir Lng 100-105. Pretoria: University of South Africa.

Emenanjo, E. 1996. The Modernization of the Igbo Language and its Implications for Holistic Education. Paper delivered at the Colloquium on Harmonising and Standardising African Languages for Education and Development, University of Cape Town, 11-14 July 1996. Unpublished mimeo.

Fishman, J. (Ed). 1974. Advances in Language Planning. The Hague: Mouton.

Glaughton, J. and D. Gough. 1996. Standard Nguni: An Alternative Proposal. Paper delivered at the Colloquium on Harmonising and Standardising African Languages for Education and Development, University of Cape Town, 11-14 July 1996. Unpublished mimeo.

Louwrens, L. 1997. On the Development of Scientific Terminology in African Languages: The Terminographer's Dilemma in a New Dispensation. Lexikos 7: 245-251.

Miyamoto, M. 1996. The Modemization of the Japanese Language in Comparison to Swahili. Paper delivered at the Colloquium on Harmonising and Standardising African Languages for Education and Development, University of Cape Town, 11-14 July 1996. Unpublished mimeo.

Msimang T. 1996. The Nature and History of Harmonisation of South African Languages. Paper delivered at the Colloquium on Harmonising and Standardising African Languages for Education and Development, University of Cape Town, 11-14 July 1996. Unpublished mimeo.

Nhlapo, J. 1944. Bantu Babel: Will the Bantu Languages Live? Cape Town: The African Bookman. 